\title{
STUDIES ON ENZYMATIC AND COAGULATING PROPERTIES OF JIBEN (Solanum dubium) SEED EXTRACTS \\ Talib, M.A..$^{*}$; M.M. Abubakar ${ }^{2}$ and I.A. Jideani ${ }^{2}$ \\ 1* Department of Biology, Faculty of Pure and Applied Science, University of Ndjamena, P.O.Box 1027, Chad. \\ 2 Department of Animal Science, School of Agriculture, Abubakar Tafawa Balewa University, P.M.B. 0248, Bauchi, Nigeria.
}

\begin{abstract}
Studies were carried out to determine the coagulating properties of Jiben (Solanum dubium) seed extracts. In this study Jiben seeds were extracted with both water and citrate phosphate buffer. The solutions were kept in dark brown bottles in the refrigerator $5 \pm 1^{\circ} \mathrm{C}$. The effect of enzyme concentration, milk pH, milk temperature and heat inactivation of crude enzyme on the clotting activity was measured. Results showed that Jiben clotting time decreased by increasing concentration of Jiben seed extracts. Increasing the $\mathrm{pH}$ of the milk over 6.2 decreased the clotting activity of the enzyme. The clotting activity of enzyme was greatly affected by the temperature of the milk. Increasing milk temperature above $40^{\circ} \mathrm{C}$ decreased the clotting time. The activity of the enzyme was lost on exposure to temperature $60^{\circ} \mathrm{C}$ at $\mathrm{pH} 3.6$ for 10 minutes. At $\mathrm{pH} 4.6,5.6$ and 6.6 and temperature $70^{\circ} \mathrm{C}$ the enzyme activity was not affected, but it lost its activity at $80^{\circ} \mathrm{C}$ for 10 minutes.
\end{abstract}

\section{INTRODUCTION}

Due to predicted world wide shortage of calf rennet for the manufacture of cheese a great deal of research has been directed towards finding suitable alternative for calf rennet (Craw, 1983). The shortage has forced cheese makers to use other enzymes, with a good milk clotting properties and can produce cheese with desirable qualities (El-Shamei and Gouda, 1990). Cyprosins (Cynarases) are aspartic proteinases present in the aqueous extract of Cardoon (Cynara cardunculus L.) flowers used as milk coagulant for the manufacture of some Portuguese and Spanish traditional cheeses. Cyprosins have an activity on k-casein similar to that of rennin and a pronounced specific activity on the other casein fractions (Queiroz et al., 1993). The milk clotting enzyme from the latex, stem and leaves of Sodom apple (Calotropis procera) has been used traditionally in Nigeria for the manufacture of a soft bodied cheese called Warankasi (Ibiama and Griffiths, 1987).

Jiben is a noxious weed belonging to the plant family Solanaceae that grows in vast areas in Chad and Sudan. It is a perennial plant that flourishes during the rainy season and usually dry on the stem, and their thorny surface causes them to stick to grazing animals and facilitates seed dissemination. Animals do not eat $S$. dubium possibly because of its taste and thorny leaves (Yousif et al., 1996).

1* Author to whom correspondence should be addressed.

Tel.: (235) $6447724 \quad$ Fax: (235) $524033 \quad$ E-mail: mohamed.talib@yahoo.fr 
Talib, M.A. et al.

Domiati cheese is considered the most popular soft cheese in Egypt and in other middle eastern countries is usually made from buffaloes milk, cow milk or a mixture, but is also made from sheep or goat milk. This soft cheese has been made from pasteurized milk addition of 2 to $15 \%$ Salt $(\mathrm{NaCl})$. Talib et al. (2006) used an inclusion level of $3 \mathrm{ml}$ Jiben seed extracts per Kilogram milk at $40^{\circ} \mathrm{C}$ for the production of white pickled cheese. Domiati cheese has also been made with or without the addition of starter cultures to cheese milk (Mehaia, 1993).

Milk coagulation is the primary step in the production of most dairy products (Hebert et al., 1999). Milk which has been heated at temperature $70^{\circ} \mathrm{C}$ for sufficient duration has longer coagulation time, and forms a weaker curd than un heated milk (Singh, 1995). A longer rennet coagulation time (firmer coagulum at cutting) resulted in an increase in cheese moisture as well as an increase in cheese yield (Johnson et al., 2001). Cheeses without active coagulant did not show degradation at the end of ripening Argentinean soft cheese Cremoso Argentino (Hynes et al., 2001). If proteolytic activity is excessive, cheese yield and retention fat in the curd may be diminished. Excessive proteolytic activity during ripening has undesirable effects on the body and texture of finished cheese (Yousif et al., 1996).

Quantification of milk activity in solutions containing proteolytic enzymes is a major concern in industrial cheese making and cheese research (Carloson et al.., 1985). Many assay techniques for quantifying renneting activity have been describes (Lowry, 1951; Holmes et al., 1977 and Carlson et al., 1985). The objective of the current research was to determine factors (enzyme concentration, $\mathrm{pH}$ and temperature) affecting the activity of Jiben seeds extract as milk coagulant and a substitute for calf rennet in cheese production.

\section{MATERIALS AND METHODS}

All chemicals used were of BDH grade and re-distilled water was used for preparation of all solutions. Glassware was soaked in $10 \%(\mathrm{v} / \mathrm{v}) \mathrm{HNO}_{3}$ for 24 hours and rinsed three times with distilled water before used. All solutions were prepared by dissolving the appropriate weight for each in re-distilled water and standardized according to standard methods (Vogel, 1978).

\section{Source of Milk:}

Milk was obtained from herds of White Fulani and Red Bororo in Ndjamena, Chad and Bauchi, Nigeria, the milk was collected using 20 litre capacity plastic containers and transported to the laboratory.

\section{Source of Jiben Seeds:}

The dried seeds of Jiben were collected from the surrounding bushes on Ndjamena, during the month of January threshed, decorticated manually and stored in the refrigerator until required.

\section{Extraction of Crude Enzyme From Jiben Seeds:}

\section{Extraction with water:}

The best of the 20 combinations prepared in terms of clotting time, coagulation time and organoleptic properties $15 \mathrm{~g}$ of Solanum dubium seeds and $8 \mathrm{~g} \mathrm{NaCl}$ was selected. This was dipped in a $250 \mathrm{ml}$ flask containing 100 
$\mathrm{ml}$ distilled water for two days at room temperature. The solution was filtered through muslin cloth in brown glass jar and kept in the refrigerator until required (Talib et al., 2006).

\section{Extraction with buffer:}

The $15 \mathrm{~g}$ Soalnum dubium seeds were extacted in $100 \mathrm{ml}$ of citrate phosphate buffer (Lillie, 1945) pH 3.6, 4.6, 5.6 and 6.6 containing $8 \mathrm{~g} \mathrm{NaCl}$ $(\mathrm{w} / \mathrm{v})$. Extracts were stirred using continuous automatic shaker at $25^{\circ} \mathrm{C}$ with speed of 150 rotator per minute for 3 hours. The solutions were then centrifuged at $3000 \mathrm{rpm}$ for 5 minutes and the precipitate removed. The solutions were then divided into $50 \mathrm{ml}$ portions in dark brown bottles and stored in the refrigerator until required (Talib et al., 2006).

\section{Assay of Milk Clotting Time and Milk Clotting Activity:}

Some $10 \mathrm{ml}$ of the fresh milk )pH 6.5) were placed in a $40 \mathrm{ml}$ capacity beaker and the contents heated up to $40^{\circ} \mathrm{C}$ using a constant temperature water bath. Then $1 \mathrm{ml}$ of Jiben seed solution was added. Curde formation was observed by manually rotating the beaker continuously so as to observe formation of a thin film on the milk surface. The end point was taken instantly when discrete milk particles appeared. A stopwatch (chronometer) was used to record the clotting time in seconds (Metwalli et al., 1982). The milk clotting activity was calculated (Ibiama and Griffths, 1987) as follows:

$$
\mathrm{X}=100 \mathrm{D} / \mathrm{T}
$$

Where: $\mathrm{D}=$ Dilution or quanity of milk containing $1 \mathrm{ml}$ of crude enzyme.

$$
\mathrm{T}=\text { Clotting time in seconds. }
$$

\section{Effect of Enzyme Concentration on Clotting Time:}

An experiment to determine the effect of crude enzyme concentration $(0.02,0.04,0.06,0.08$ and 0.10$)$ on milk clotting activity was conducted using $0 \mathrm{ml}$ of fresh milk and different quantities $(0.2,0.4,0.6,0.8$ and $1.0 \mathrm{ml})$ of crude enzyme. The clotting time was determined according to Metwalli et al., 1982).

\section{Effect of Milk Temperature on Clotting Activity:}

The activity of the enzyme at various milk temperature $(20,30,40,50$ and $60^{\circ} \mathrm{C}$ ) was measured. One $\mathrm{ml}$ of the crude enzyme was added to $10 \mathrm{ml}$ of each heated milk. The clotting activity was determined according to Metwalli et al. (1982).

\section{Effect of Milk pH on Clotting Activity:}

The activity of enzyme at various $\mathrm{pH}$ was determined by adjusting the $\mathrm{pH}$ of the milk to the desired $\mathrm{pH}$ from 6.2 to $6.8(6.2,6.4,6.6$ and 6.8). One $\mathrm{ml}$ of the crude enzyme was added to $10 \mathrm{ml}$ of each of these solutions to determine the effect of $\mathrm{pH}$ on clotting time as proposed by Metwalli et al. (1982).

\section{Effect of Heat Inactivation on the Clotting Time:}

To determine the effect of heat inactivation on the clotting activity, the crude Jiben extracts in test tubes were heated at 60,70 and $80^{\circ} \mathrm{C}$ for ten minutes, cooled immediately in an ice water bath and then used for clotting test according to Metwalli et al. (1982). 
Talib, M.A. et al.

\section{RESULTS AND DISCUSSION}

The effect of enzyme concentration on clotting activity is shown in Fig. (1). The effect of varying concentrations of enzyme upon clotting activity on milk was proportional to the concentrations of crude enzyme. It was noted that lower concentrations of crude enzyme showed less activity than higher concentrations. The results are in agreement with those stated by Magdoub et al. (1984) and Gouda and El-Shamei (1990) who mentioned that increasing concentration of rennet decreased rennet clotting time.

The effect of milk temperature on the clotting activity is illustrated in Fig. (2). The clotting activity process was greatly affected by the temperature of the milk. When the temperature of the milk was increased above $40^{\circ} \mathrm{C}$ the clotting activity decreased very rapidly. The maximum speed on coagulation was obtained at $40^{\circ} \mathrm{C}$. The rate of change on clotting activity per unit change of temperature up to $50^{\circ} \mathrm{C}$ decreased very rapidly as the temperature increased. Gouda and El-Shamei (1990) found that the milk clotting activity of chicken pepsin increased as $\mathrm{pH}$ decreased from 6.0 to 6.6, and with increase in temperature from 30 to $55^{\circ} \mathrm{C}$.

The effect of milk $\mathrm{pH}$ on the clotting activity of crude enzyme extract from Jiben seeds ranged from $\mathrm{pH} 6.2$ to 6.8 is shown in Fig. (3). The pH of the milk has a pronounced effect on the clotting activity. The increase of the clotting activity was directly proportional to the decrease in the $\mathrm{pH}$ of milk. Results indicated that increasing the $\mathrm{pH}$ over 6.2 decreased the clotting activity. Storry and Ford (1982) and Okigbo et al. (1985) found that rennet clotting time was decreased by reducing $\mathrm{pH}$.

The effect of temperature 60,70 and $80^{\circ} \mathrm{C}$ and $\mathrm{pH} 3.6,4.6,5.6$ and 6.6 for 10 minutes on the coagulant solution is shown in Fig. (4). The enzyme lost its activity at $60^{\circ} \mathrm{C}$ for 10 minutes and at $\mathrm{pH} 3.6$. At 60 and $70^{\circ} \mathrm{C}$ and pH 4.6, 5.6 and 6.6 the crude enzyme was found to be stable and its clotting activity was not affected, but it lost its activity at higher temperature $80^{\circ} \mathrm{C}$ or at $\mathrm{pH} 4.6,5.6$ and 6.6 and no activity was observed after 10 minutes.

\section{CONCLUSION}

It could be concluded that increasing the concentration of crude enzyme decreased clotting time. The maximum activity was recorded at $40^{\circ} \mathrm{C}$ over that temperature a loss in enzyme activity was observed. Increasing the $\mathrm{pH}$ over 6.2 decreased the clotting activity. Heat treatment to inactivate Jiben seeds extract was found to be higher than heat used in the pasteurization. So more heat treatment is required to inactivate the residual crude in the whey when used as brine (Gouda, 1990). Since Jiben, shows a highly specific milk clotting activity, it can be used as a milk coagulant and a substitute for calf rennet. 
J. Agric. Sci. Mansoura Univ., 32 (9), Sptember, 2007 
Talib, M.A. et al. 


\section{REFERENCES}

Carlson, A., Hill, C. and Olson, N. (1985). Improved assay procedure for determination of milk clotting enzymes. J. Dairy Sci. 68: 290 - 299.

Craw, R.J. (1983). Future development in rennet and its use in the cheese factory, p. 14. In: International Dairy Federation Bulletin, No. 194. International Dairy Federation. Brussels, Belgium.

El-Shamei, Z. and Gouda, A. (1990). Studies on chicken pepsin I-Isolation and purification. Egyptian Journal of Food Science, 18(1-3): 245 225.

Gouda, A. (1990). Studies on Chicken Pepsin. III- Storage Stability and Thermal-inactivation. Egyptian Journal of Food Science, 18(1-3): 291 296.

Gouda, A. and El-Shamei, Z. (1990). Studies on Chicken Pepsin. IIParameters affecting activities and properties of two chicken pepsins. Egyptian Journal of Food Science, 18(1-3): $201-210$.

Herbert, S., Riaublanc, A., Bouchet, B., Gallant, D. and Dufour, E. (1999). Fluorescence spectroscopy investigation of acid rennet-induced coagulation of milk. J. Dairy Sci. 82: 2056 - 2062.

Holmes, D.G., Duerch, J.W. and Ernstrom, C.A. (1977). Distribution of milkclotting enzymes between curd and whey and their survival during Cheddar cheese making. J. Dairy Sci., 60: 862.

Hynes, E.R., Meinardi, C.A., Sabbag, N., Cathaneo, T., Candioti, M.C. and Zalazar, C.A. (2001). Influence of milk clotting enzyme concentration on the Alphas. I- Casein hydrolysis during soft cheeses ripening. Journal of Dairy Science. 84(6): 1335 - 1340.

Ibiama, E. and Griffiths, M.W. (1987). Studies on a milk-coagulating enzyme Calotropain, obtained from Sodom Apple (Calotropis procerd). Journal of Food and Agriculture. 1(3): 157 - 162.

Johnson, M.E., Chen, C.M. and Jaeggi, J.J. (2001). Effect of rennet coagulation time on composition, yield and quality of reduced-fat Cheddar cheese. Journal of Dairy Science, 84: 1027 - 1033.

Lillie, R.D. (1945). Histopathologic Technique. Blackiston. Philadelphia and Toronto.

Lowry, O.H. Rosenbrough, N.J. and Randall, R.J. (1951). Protein measurement with the Folin-phenol reagent. J. Biol. Chem. 193265.

Magdoub, M.N., Sultan, N., Hegazi, N. and Shehata, A.E. (1984). Effect of adding calcium chloride to the rennet on milk clotting activity. Asian Journal of Dairy Research. 2(4): 218 - 220.

Mehaia, A.M. (1993). Fresh soft white cheese (Domiati-type) from camel milk: Composition, yield and sensory evaluation. Journal of Dairy Science, 76(10): 2845 - 2855.

Metwalli, N.H., Shalabi, S.I., Zharan, A.S. and El-Demerdash, O. (1982). The use of soy property of milk. Journal of Food Technology. 17: 71- 77.

Okigbo, L.M., Richardson, G.H. Brown, R.J. and Ernstrom, C.A. (1985). Variation in picon, coagulation properties of milk from individual cows. Journal of Dairy Science. 68: 822 - 828. 
Talib, M.A. et al.

Queiroz, M.I., Faro, I.C. and Pires, E.M. (1993). Specificity and kinetics of the milk clotting enzyme from Cardoon (Cynara cardunculus, L.) toward bovine k-casein. Agricultural Food Chemistry, 41: 1537 - 1540.

Singh, H. (1995). Heat-induced changes in casein, including interactions with whey proteins. In heat-induced changes in milk. $2^{\text {nd }}$ ed. Ed. P.F. Fox. pp. 86 - 104 Int. Dairy Federation, Brussels.

Storry, J.E. and Ford, G.D. (1982). Some factors affecting the post clotting development of coagulum strength in rennet milk. Journal of Dairy Research, 49(3): 469 - 477.

Talib M.A., Abubakar, M.M. and Jideani, I.A. (2006). Effect of different concentration of Jiben (Solanum dubium) seed extracts on the physicochemical and organoleptic properties of soft cheese. J. Agric. Sci. Mansoura Univ., 31(11): 6951 - 6957.

Vogel, A.I. (1978). A Textbook of quantitative inorganic analysis. $4^{\text {th }}$ ed., Longman, London.

Yousif, B.H., McMahon, D.J. and Shammet, K.M. (1996). Milk clotting enzyme from Solanum dubium plant. International Dairy Journal. 6: $637-644$.

\footnotetext{
دراسة الصفات الإنزيمية والتخثرية لمستخلص بذور بـو نبات الجبين

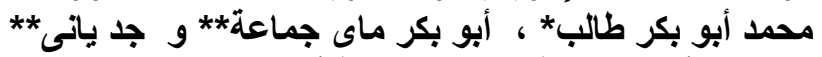

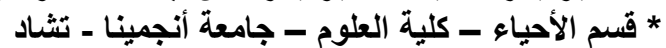

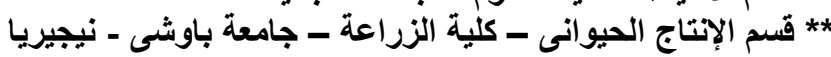

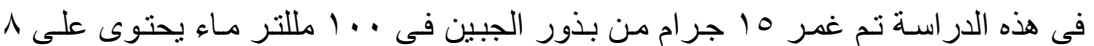

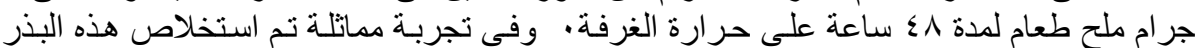

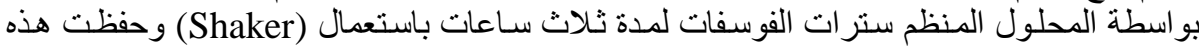

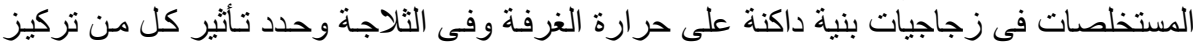

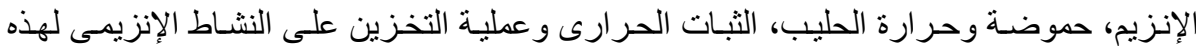

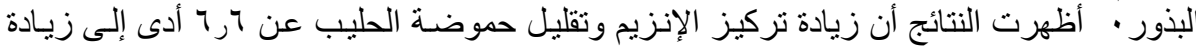

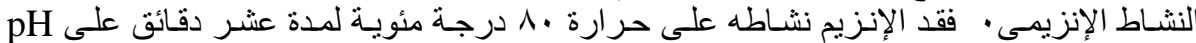

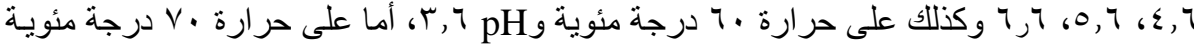
ا 7 pH
} 